\title{
MITEN VERKOSSA OPITAAN, KUN TIETOTEKNISET VALMIUDET OVAT HEIKOT?
}

\author{
Ammattienedistämislaitos, AEL on hyödyntänyt verkko-oppimista \\ koulutuksessaan jo pitkään. Verkko-oppimista hyödyntävä kiinteistön- \\ hoitajien kokeilukoulutus käynnistettiin AEL:n aloitteesta keväällä 2001. \\ Hanke nimettiin KH-NET -projektiksi. Sen koulutuksellisena tavoitteena \\ oli kiinteistönhoitajan ammattitutkinnon suorittaminen tietokone- \\ painotteisella koulutuksella. Projektiin kytkettiin alusta alkaen myös \\ tutkimus, josta vastasi Tampereen yliopiston ammattikasvatuksen tutki- \\ mus- ja koulutuskeskus. Projekti sai tukea Etelä-Suomen lääninhallituk- \\ selta ja Euroopan sosiaalirahastolta.
}

SEPPO SAARI

$\mathrm{K}$ oulutusprojektin kokonaistavoitteena oli kehittää internetiä hyödyntävä valmentähtäsivät alan ammattitutkintoon. Tavoitteena oli integroida teoreettista tietoa ja työelämää tietoverkkoja hyväksi käyttäen. Oppimisen lähtökohtana pidettiin käytännön työelämän tarpeita. Tavoitteena oli lisätä kiinteistönhoito-organisaatioiden työpaikkakouluttajien ja esimiesten valmiuksia osallistua oppimisprosessiin sekä työntekijöiden oppimisen tukemiseen erityisesti pedagogiikan ja uuden opetusteknologian hyödyntämisessä. Koulutuksessa erityinen tavoite asetettiin tutorointiin yksilö- ja ryhmätasolla sekä eri toimijoiden rooliin ja yhteisölliseen oppimiseen. Valmennusohjelman tavoitteena oli yhdistää teoreettista tietoa ja käytännön osaamista.

Tutkimuksen tavoitteena oli selvittää verkkooppimista, verkkopedagogiikkaa ja tutorointia verkossa. Tutkimukseen osallistui 18 opiskelijaa

\section{OPPIMISALUSTA} YHTEYDENPITOVÄLINEENÄ

Koulutuksessa käytettiin WebCT -oppimisalustaa, joka oli koulutuksen alussa englanninkieli- nen, mutta suomennettiin koulutuksen kestäessä. Oppimisalusta aukeaa AEL:n pääsivuilta ja kurssin sivuille pääseminen edellytti käyttäjätunnuksen ja salasanan käyttöä. Näin oppimisalustalla oleva keskustelu oli vain kurssin opettajien ja kurssilaisten käytössä. Tutkijalla oli oma tunnuksensa oppimisalustaan, josta saattoi seurata kurssin tapahtumia. Kurssin pääsivulta saattoi valita linkin kurssiaineistoon, yhteydenpitovälineisiin tai kalenteriin.

Pääsivu oli selkeä ja ohjelman suomennoksen jälkeen opiskelijoilta tullut palaute kertoi etsimisen ja liikkumisen sivuilla helpottuneen. Tietoliikenteeseen liittyvänä ongelmana oli joillakin opiskelijoilla työpaikan tai kotikoneen yhteyden hitaus.

Tutkijalla oli oppimisalustassa oma osa, johon opiskelijoilla oli mahdollisuus tutustua. Toivotuista tutkimukseen liittyvistä aktiviteeteista tiedotettiin sekä lähijaksoilla suullisesti, kirjallisesti että oppimisalustassa. Ensimmäisen vaiheen (vuonna 2001) motivaatiokyselyn tulokset julkaistiin myös oppimisalustassa. Tuloksia esiteltiin myös lähijakson aikana ja opiskelijoille jaettiin tuloksista henkilökohtaiset palautteet.

Opiskelijoilla oli koko opintojen ajan verkkotuutori, joka vastasi aktiivisesti ja nopeasti opiskelijoiden kyselyihin. Ohjaajien ja opiskelijoiden 
vuorovaikutus lähipäivien väliaikana toteutui WebCT -oppimisalustassa.

Opiskelijoille jaetun kirjallisen opiskeluaineiston lisäksi aineistoa oli saatavilla WebCT-oppimisalustassa, josta sitä saattoi tulostaa itselleen. Kurssien pitäjät antoivat opiskelijoille myös Internet-osoitteita, joista sai aiheisiin liittyvää lisätietoa. Samalla opiskelijoita ohjattiin suhtautumaan Internetin kautta saatavaan aineistoon kriittisesti ja arvioimaan tiedon oikeellisuutta.

Koulutukseen kuului verkossa vastattavia harjoitustehtäviä, jotka saattoi toimittaa verkon kautta tarkistettaviksi. Harjoitustehtävien avulla saattoi valmentautua näyttökokeisiin. Kurssin tuutori oli laatinut verkkoon tehtäviä, joista sai automaattisen korjatun palautteen. Testeihin liittyviä asioita saattoi tarkentaa tuutorilta sähköpostitse. Opiskelijat käyttivät mahdollisuutta ahkerasti (93 kysymystä ja 94 tuutorin kirjoittamaa henkilökohtaista vastausta, jotka eivät olleet julkisessa sähköpostikeskustelussa).

Verkkoon sijoitettu opiskeluaineisto oli pääosin tekstiä ja kuvaa. Varsinaisesti pedagogisesti rakennettua opintoainesta ei testien lisäksi ollut käytettävissä. Harjoitustestejä voi pitää pedagogisesti motivoivina, koska testin saattoi suorittaa milloin tahansa ja siihen sai nopeasti vastauksen. Opiskelijat käyttivät opiskelun aikana WebCT:n yhteydenpitoon lisäksi puhelinta, matkapuhelinta ja AEL:n sähköpostiosoitetta. Monet opiskelijat eivät epäröineet soittaa tuutorille, kun opinnoissa oli kysyttävää tai ongelmia. Lähipäivinä opiskelijat saivat toistuvasti tukea verkon käyttöön. Koska osalla opiskelijoista jäi kurssin jälkeen jokin näyttökoe suorittamatta, ovat opiskelijat käyttäneet verkossa olevia valmennustehtäviä kurssin jälkeen. Tätä voidaan pitää verkko-aineiston merkittävänä vahvuutena. Myös sähköpostiviestiminen on jatkunut kurssin jälkeen.

\section{VERKKO-OPPIMISEN VUOROVAIKUTUSSUHTEET}

Opiskelijat saivat antamansa palautteen mukaan hyötyä verkkotuutoroinnista. Suurin osa varsinaisista KH-NET -opiskelijoista myös hyödynsi verkkotukea. Tuen tarve verkon käyttöön oli kuitenkin jonkin verran tarjottua suurempaa. Monien työpaikat eivät tukeneet tietokoneen käyttämisen mahdollisuutta opiskelijan halutessa. Monille opiskelijoille tietokoneen käyttöön liittyvät

\section{AEL}

AEL on Suomen suurin tekniikan alan lisäkouluttaja. Varsinaisesta ammattien edistämisestä AEL on siirtynyt henkilöstön kehittämiseen, missä ammattitaidon edistäminen on yksi painopisteistä. Tärkeimpänä pidetään jatkuvaa oppimista. AEL:n tehtävä on tukea elinkeinoelämän menestystä. Taustavoimia ovat keskeiset työmarkkinaosapuolet, julkishallinto ja elinkeinoelämä Ammattienedistämissäätiö AEL:n kautta.

Oleellisena osana verkostoa on lisäksi valtakunnallinen asiantuntijaverkosto, johon kuuluu yli 3000 eri alojen asiantuntijaa tutkimuslaitoksista, korkeakouluista ja yrityksistä. Ulkopuolisilla asiantuntijoilla on keskeinen rooli koulutuksen suunnittelussa.

Asiantuntijaverkosto ja asiakkaiden kautta AEL saa viimeisimmän tiedon eri alojen kehityksestä ja kehitystarpeista.

TAMPEREEN YLIOPISTON AMMATTIKASVATUKSEN TUTKIMUS- JA KOULUTUSKESKUS

TaY:n ammattikasvatuksen tutkimus- ja koulutuskeskus harjoittaa erityisesti ammatilliseen oppimiseen liittyvää tutkimusta. Yksikkö on kehittänyt yhteistyössä muun muassa Helsingin yliopiston kanssa uusia monimuuttujien mallintamismenetelmiä.

Tutkimusyksikkö on soveltanut uusia menetelmiä myös oppimiseen liittyvän motivaation ja itsesäätelyn mallintamiseen. (Ruohotie \& Pintrich 2002)

hankaluudet muodostuivat sujuvan ja tarpeellisen käytön esteeksi.

Opiskelijoilla oli selvästi korkeahko kynnys kirjoittaa verkkoon. Kirjallisen tuottamisen kynnyksen madaltaminen on selvästi tulevien koulutusten haasteita. Käsitys itsestä "heikkona" kirjoittajana saattoi muodostua osalle opiskelijoista esteeksi tekstin tuottamiselle. Kun siihen yhdistyi epävarma tietotekninen osaaminen, oli kynnys jo muodostunut selvästi esteeksi tekstin tuottamiselle.

KH-NET -kurssilaisten sähköpostiaktiivisuus mitattiin laskemalla yhteen luetut ja lähetetyt viestit. Näin KH-NET -opiskelijoiden viestien osuus oli (1472/2013) eli 73 prosenttia. Verkossa käyntien lukumäärä oli KH-NET -opiskelijoilla 10 259 käyntikertaa, mikä on 74 prosenttia kaikista kurssin opiskelijoiden käynneistä (13 952).

Verkossa varsinaiset KH-NET -opiskelijat olivat tutustuneet opiskeltavaan aineistoon 2239 kertaa, mikä on 25 prosenttia saman ryhmän ver- 
kossa käynneistä (2239 / 8957). Verkossa käynti ei sinänsä kerro vielä kuin osan aktiviteeteista. Merkittävää on se kuinka kauan opiskelija on tutkinut verkkoaineistoa. Siitäkään ei kuitenkaan saa todellista kuvaa. Verkkoyhteys voi toimia hitaasti, jolloin vierailuaika ja voi olla pitkä, mutta hyödynnettävä aika varsin lyhyt. Myös lyhytaikainen vierailu, jolloin verkkoaineisto on vain tulostettu tai tallennettu omalle koneelle, saattaa kuitenkin olla käytännössä aktiivisen opiskelun kannalta merkittävää.

Koko kurssin opiskelijoiden postittamien viestin määrä oli 156. Sähköpostissa ei syntynyt varsinaisesti keskustelua, mutta se toimi lyhyiden viestin tehokkaana välineenä.

\section{VERKKOKESKUSTELU}

Oppimisalustan kaikille opiskelijoille avoimena käyty sähköpostikeskustelu oli aluksi hyvinkin tunnustelevaa ja selvästi arkaa. Kysymykset olivat jatkossakin lyhyitä ja keskittyivät olennaiseen. Opettajien ja tuutoreiden kysymykset ja vastaukset olivat perusteellisia ja osoittivat opiskelijoista huolehtimista. Opettajien huumorintaju ilmeni muun muassa tekstin sisällön kevennyksinä. Opiskelijat ilmaisivat asiansa suoraan ja ilman sovinnaisuuksia ja kohteliaisuuksia. Kurssin lopuksi (kesällä 2002) pari opiskelijaa heltyi toisten lohduttamiseen ja kurssista kiittämiseen.

Kurssin opettajista vain kurssivastaavat ja yhden erityisalan opettaja ottivat osaa keskusteluun. AEL:n ulkopuoliset opettajat eivät käyttäneet oppimisalustan keskustelu- ja sähköpostimediaa.

Keskustelulla oli selvä rakenne: opettaja tiedotti, kysyi ja vastasi nopeasti ja selkeästi. Opiskelijat kommentoivat lyhyesti ja kokeillen. Kärsimättömyys näyttökokeiden tuloksien nopeasta saamisesta ilmeni useissa viesteissä. Suoraan tuutorin kanssa käyty keskustelu keskittyi opiskelijoiden lähettämiin etätehtäviin ja tuutorin vastauksiin. Samoin tässä osassa tuutori lähetti näyttökokeiden hyväksymis- ja hylkäämistiedot opiskelijoille, jolloin viestit eivät olleet kuin vastaanottajan luettavissa.

Joillekin opiskelijoille kirjoittaminen oli selvästi ylivoimaista. Heiltä puuttuivat todennäköisesti tietokoneella kirjoitetun tekstin korjaamisen taidot. Sähköpostin käyttöä oli varmasti estänyt puutteellinen näppäimistöllä tapahtuva kirjoitustaito.
On otettava huomioon, että sähköpostikeskustelulla tarkoitettiin pääosin julkista oppimisalustassa ollutta keskustelupalstaa, joka opiskelijatilastojen mukaan oli vaatimatonta. Tämän ohessa sähköpostia käytettiin yhteydenotoissa suoraan tuutoriin kysymyksissä, jotka liittyivät muun muassa näyttökokeiden verkon kautta harjoiteltaviin tehtäviin.

Jos verkkokeskustelun aktiviteettiin liittyviä tuloksia arvioi suhteessa ennakko-odotuksiin, voidaan todeta, että sähköpostikeskustelulle asetetut ennakko-odotukset olivat epärealistisia. Koulutuksen aikana opiskelijalle syntyi kuitenkin kokemus sähköpostiviestimen käytön mahdollisuuksista. Opiskelijan saama todellinen hyöty on ollut todennäköisesti huomattavasti suurempi kuin verkon käytön aktiivisuuden kautta voidaan suoraan arvioida. Samoin opiskelijan itsensä on ollut vaikea arvioida saamaansa hyötyä ja suhteuttaa sitä tavanomaiseen opiskeluun, koska opiskelu yleisesti oli opiskelijoille vierasta. Verkkokeskustelun aktiviteetteja arvioitaessa on otettava huomioon myös, että kyseessä oli työn ohessa opiskelu, jolloin tietokoneen käyttö vaati ylimääräistä aikaa muun työn ja opiskelun ohessa. Voidaan päätellä, että verkossa käydystä tiedonvaihdosta on ollut erityisen suuri hyöty opiskelijalle. Samalla opettajalla oli mahdollisuus seurata opiskelijoiden yleistä aktiviteettia verkossa vierailemisessa, aineistoon tutustumisessa ja testien tekemisessä. Erityisesti ohjaajan kannalta menetelmä on hyödyllinen siksi, että ohjaaja voi koko ajan olla perillä siitä, ketkä opiskelijoista ovat aktiivisia toimijoita. Näin ohjauksella annettavaa tukea on voinut kohdistaa niille, jotka sitä erityisesti tarvitsivat. Sähköpostikeskustelussa on otettava huomioon aktiiviseen kirjoittamiseen liittyvä korkea kynnys. Sen olemassaolo ei kuitenkaan kerro siitä, etteikö viestejä olisi luettu tai oltaisi kiinnostuneita verkossa käydystä keskustelusta.

\section{MOTIVAATIO}

Opiskelijoiden motivaatiota mitattiin kahteen otteeseen opintojen aikana. Ensimmäisen vaiheen motivaatiomittaus toteutettiin toukokuu-kesäkuulla 2001. Toinen vaihe toteutettiin opintojen ollessa jo loppuvaiheessa maaliskuulla 2002. Motivaatiokyselyn ensimmäisen ja toiseen vaiheen tulokset on sijoitettu samaan taulukkoon.

Kysely perustui Ruohotien ja Pintrichin moti- 


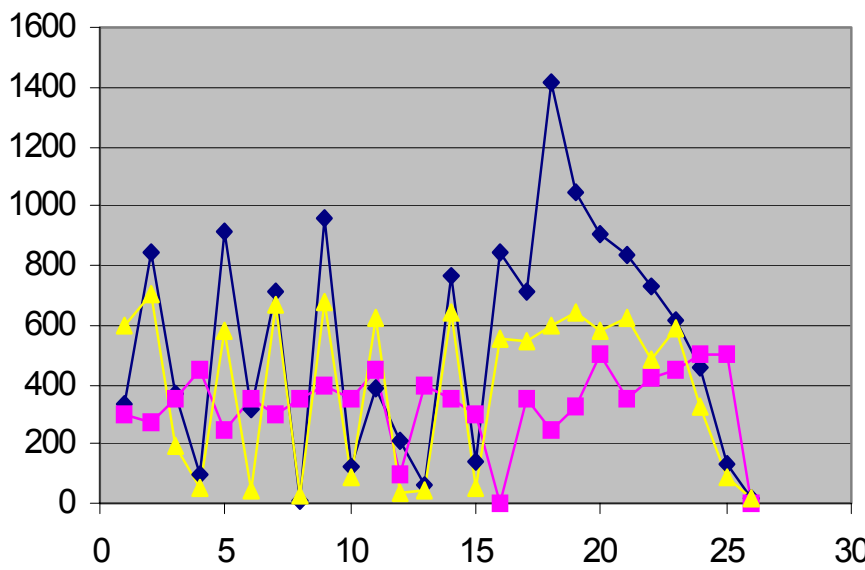

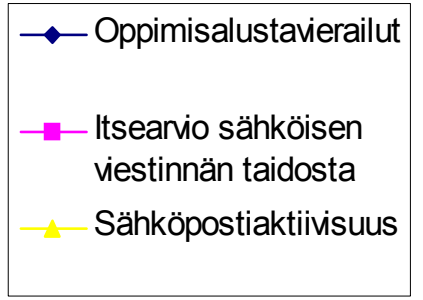

Kuvio. Oppimisalustassa

vierailut, opiskelijan itsearvio sähköisen viestinnän taidoista ja sähköpostiaktiivisuus. vaatiotutkimusaineistoon. Tutkitun ryhmän opetuksen laatuun liittyvät tulokset olivat huomattavasti korkeampia kuin laajassa korkeakouluopiskelijoiden vertailuaineistossa. AEL:n omat opettajat saivat poikkeuksetta positiivista palautetta sekä kurssien sisällöistä että opettamisen tavasta ja kurssilaisten tarpeiden huomioon ottamisesta. Opiskelijat pitivät opetuksen laatua sekä vuonna 2001 että vuonna 2002 huomattavasti korkeampana kuin korkeakouluopiskelijoiden vertailuryhmä. Erityisesti opintoja koettiin tuetun hyvin. Myös opetuksen laatu ja opettajien pätevyys oli arvioitu huomattavasti korkeammaksi kuin korkeakouluopiskelijoiden aineistossa.

Koulutuksen vaikutukset ja tulokset olivat joko samansuuntaisia kuin vertailuaineistossa tai lievästi korkeampia. Kun arvioidaan koulutuksen vaikutuksia ja tuloksia, niissä ammatissa kehittymisen valmiuksia koettiin saadun eniten.

\section{SÄHKÖISEN VIESTINNÄN TAITO}

Itsearvioinnissa sähköisen viestinnän taidoissa oli melko paljon vaihtelua. Sähköisen viestinnän taitojen yhteyttä selvitettiin erikseen myös suhteessa verkkoaktiivisuuteen. Erityisesti on huomattava, että ne, jotka olivat verkossa kaikkein aktiivisimpia, eivät välttämättä arvioineet sähköisen viestinnän taitojaan korkeimmiksi. Suoraviivainen korrelaatio verkossa vierailujen ja luettujen viestien välillä nousi korkeaksi ollen 0.83 . Korrelaatio verkossa vierailujen ja postitettujen viestien välillä jäi melko alhaiseksi ollen 0.23 . Korrelaatio luettujen ja postitettujen viestien välillä jäi myös melko alhaiseksi 0.26. Se kertonee siitä, että viestejä on luettu, mutta se ei liity siihen, onko opiskelija ollut myös aktiivinen viestien kirjoittaja. Yllättävin ortogonaalinen korrelaatio oli luettujen viestien ja opiskelijan itsensä arvioiman sähköisen viestinnän taitojen välillä, joka oli nollakorrelaation tasoa (- 0.026). Näin voidaan väittää, että henkilön oma arvio sähköisen viestinnän taidoista ei liity ollenkaan verkossa tapahtuneeseen aktiivisuuteen opintojen aikana. Tuloksiin liittyviä päätelmiä vaikeuttaa se, että opiskelijoiden oppimisalustan ulkopuolisista suorista viesteistä tuutoreille ei ollut tilastoja.

Kuviossa on yhdistetty myös muu sähköpostiaktiivisuus kuin ryhmän avoimessa oppimisalustassa käyty keskustelu. Oheisessa taulukossa ovat oppimisalustassa vierailut, opiskelijan itsearvio sähköisen viestinnän taidoista ja sähköpostiaktiivisuus. $\mathrm{X}$-akselilla ovat opiskelijakohtaiset tulokset ja yakselilla suureet. Jotta käyriä voitiin tarkastella samassa kuviossa suhteessa toisiinsa, on sähköisen viestinnän taidot kerrottu sadalla ja sähköpostiaktiivisuus viidellä.

Kuviosta voi päätellä, että oppimisalustassa tapahtuneiden vierailujen ja sähköpostiaktiivisuuden välillä oli korkea keskinäinen ortogonaalinen positiivinen korrelaatio (0.83). Sen sijaan korrelaatio sähköisen viestinnän taitojen ja oppimisalustassa vierailujen lukumäärän välillä on melko alhainen ( 0.23$)$ ja toisaalta sähköisen viestinnän taitojen ja sähköpostiaktiivisuuden välinen korrelaatio oli nollakorrelaation tasolla (0.09). Myös laajennetulla aineistolla korrelaatio sähköpostiaktiivisuuden ja opiskelijan sähköisen viestinnän taitojen välinen korrelaatio jäi nollakorrelaation tasolle (- 0.03$)$. On otettava huomioon, että korrelaatiot laskettiin vain ortogonaalisella mallilla. 
JOHTOPÄÄTÖKSIÄ

MOTIVAATIOMITTAUKSESTA

On luonnollista, että tutkitussa ryhmässä oli oppijoita, joiden oppimisen taidot olivat pääosin vaatimattomia. Se ilmeni tavoitteiden asettamisessa omalle oppimiselle, joka jäi helposti yleisluonteiselle tasolle. Samalla näillä opiskelijoilla oli heikot edellytyksen toiminnan kontrolliin ja itsereflektioon. Ego-orientoituminen vaikutti myös siihen, että kynnys käydä julkista keskustelua verkossa nousi korkeaksi. Tehokkuususkomuksiin liittyvä omiin kykyihin kohdistuva heikko luottamus saattoivat estää myös avoimen kommunikoinnin. Tähän liittyi opiskelijoiden poikkeuksellisen alhaiset arviot verkossa oppimisen taidoistaan. Samoin oman oppimisprosessin tarkkailu ja oppimisprosessin hallinta oli tutkitulla ryhmällä varsin sattumanvaraista. Nämä kaikki kertovat siitä, että kyseessä on melko alhainen oppimisen taitojen taso. (Ruohotie 1998, 78 - 79.) Se on todennäköisesti myös osasyynä siihen, että verkon hyödyntämisessä opintoihin oli tavanomaista suurempia vaikeuksia.

\section{TULOSTEN HYÖDYNTÄMINEN}

Tutkimuksessa jäi hyödyntämättä loppukysely oppimisalustassa sekä keskeyttäneiden haastattelu puhelimitse. Ryhmän tuutori oli kuitenkin yhteydessä keskeyttäneisiin eri vaiheissa ja sai keskeyttämisen syistä palautetta. Keskeyttämisen syynä oli muun muassa työnantajan kielteinen suhtautuminen koulutukseen tai opiskelija koki yleisen elämäntilanteensa estävän opinnot. Verkon käyttöön liittyviä keskeyttämisen syitä ei tullut esille opintojen aikana.

Tutkimusta voidaan hyödyntää verkkopohjaisen opetuksen edelleen kehittämisessä. Merkittävää oli, että tutkimuksessa selvitettiin syrjäytymisuhan alaisena olevien opiskelijoiden tietoteknisiä valmiuksia ammatin opinnoissa. Samalla selvitettiin verkon kautta saatavaa lisäarvoa opintoihin. Motivaatiomittauksen kytkeminen arviointiprosessiin tarjosi standardoidun aineiston käyttömahdollisuuden, jolloin opiskelijoiden tuloksia voitiin verrata suurempaan otantaan. Samalla tulokset sijoittuivat tulkinnallisesti relevantisti. Tilastollisesti merkitseviä eroja ei syntynyt koe- ja vertailuryhmän välille yhdessäkään muuttujaryhmässä.

Tutkimuksen perusteella oli nähtävissä opiskelijoiden motivaation korkea taso, joka ilmeni sekä tutkinnon suorittaneiden tehokkaana opintoajan käyttönä että onnistuneina tutkintoina. Erityisen tärkeä tekijä opintojen kannalta oli työnantajan asennoituminen opintoihin, jotka veivät osan työajasta. Opiskelijan tulisi saada palautetta siitä, että opinnot ovat myös työnantajalle kannattava sijoitus. Opintojen tuottama ammattitaidon lisääntyminen ja tietojen ajan tasalle saattaminen on merkittävä kilpailuetu työnantajalle.

Yhtenä aktivoivana ja kurssilla pysymistä vakauttavana tekijänä oli selvästi tuutoreiden jatkuva yhteydenpito ryhmään. Opiskelijaryhmään oli muodostanut selvästi positiivisista oppimiskokemuksista myönteistä ryhmähenkeä, joka ilmeni opiskelijoiden positiivisina palautteina myös kurssin päätöstilaisuudessa 28.8. 2002.

Merkittäviä opintoja edistäviä tekijöitä opintojen suorittamisessa verkon tukemana olivat huolehtimisen kokemusten lisääntyminen opiskelijoilla, nopea tiedonkulku, yhteydenpito toisiin opiskelijoihin (passiivisestikin sähköposteja seuraamalla) ja opiskeluaineiston harjoittelutehtävien suoritusmahdollisuus verkossa. Voidaan olettaa, että ilman näitä tukitoimenpiteitä sekä opinnot että tutkinnot eivät olisi onnistuneet yhtä hyvin kuin tutkitulla ryhmällä tapahtui.

\section{JOHTOPÄÄTÖKSIÄ}

Tutkittavien kiinteistönhoitajien ammattitutkintoa suorittavien opiskelijoiden verkko-oppimisen valmiudet olivat opintojen alussa varsin heikot. Osalla opiskelijoista niitä ei ollut ollenkaan. Tietoteknisen koulutuksen jälkeenkään kaikilla opiskelijoilla ei ollut käytettävissä toimivaa verkkoyhteyttä.

Kuitenkin tutkimuksella oli selvästi osoitettavissa, että verkolla oli merkittävä lisä-arvo opiskelijoiden opintojen ja tulevaisuuden kannalta. Opiskelijoiden oma palaute ei kuitenkaan selkeästi tukenut olettamusta. Opiskelijoiden omat uskomukset heidän kyvyistään olivat monissa kohdin varsin heikot, ja opiskelijat eivät suureksi osaksi nähneet vielä saamansa monipuolisen koulutuksen hyötyjä. Kuitenkin ne opiskelijat, joille verkossa oleva alan aineisto oli avautunut, seuraavat todennäköisesti tulevaisuudessakin alan kehitystä myös verkosta.

Vaikka verkossa käyty yhteinen keskustelu oli vähäisempää kuin ennakkoon ajateltiin, ei verkkokeskustelun informaatioarvoa tule vähätellä. Opiskelijoiden kannalta se nopeutti ja yksinker- 
taisti tiedonkulkua. Verkossa käyntien runsas määrä antoi olettaa, että verkosta oli erityisen paljon käytännön hyötyä opiskelijoille.

Vielä enemmän lisäarvoa verkko olisi tuonut, jos työpaikkatuutorit ja kaikki lähiopettajat olisivat käyttäneet myös verkkoa lähiopetuksen lisäksi esimerkiksi antamalla ennakko-, lisä- ja harrastetehtäviä verkossa sekä antamalla palautetta myös jälkeenpäin verkossa. Näin tietoverkosta olisi saatu laajemmin yhteisen keskustelun foorumi.

Opiskelijoiden koulutustaustalla ei voitu ennusta viestien kirjoittamista, lukemista tai verkkoaktiivisuutta yleensäkään. Ahkerin viestien kirjoittaja oli ammattikoulun käynyt. Ylioppilastutkinnon suorittaneet eivät olleet muita aktiivisempia verkossa.

Koulutuksen järjestäjien olisi syytä panostaa verkkoaineiston pedagogiseen laatimiseen. Verk- koaineistojen tekeminen vaatii tekijöiltään huomattavaa ajallista panostusta. Verkkoaineistoa tulee lisäksi testata, muokata ajantasaiseksi ja ottaa jatkuvasti huomioon opiskelijoilta tullut palaute. Vuorovaikutteisuus on verkon käytön merkittävimpiä etuja, mutta sen edellyttämä aika tulee ottaa huomioon opettajien työn resurssoinnissa. Muussa tapauksessa verkkokokeilut uuvuttavat innovatiivisetkin kehittäjänsä.

Tutkimuksessa käytetyn aineiston perusteella voitiin päätellä, että verkko tuo erinomaiset lisämahdollisuudet erityisesti syrjäytymisuhan alaisille opiskelijoille. Verkon lisäarvo on lähinnä mahdollisuuksien tarjoamisessa, verkon käyttöön totuttamisessa ja oman työn kehittämisessä sekä siihen aineiston hankkimisessa. Näin tietoverkosta voi muodostua elinikäisen oppimisen kannalta ammattitaitoa ylläpitävä väline, kunhan tieto ja viestintätekniikan käytön lisääntyessä yleinen arkuus tulee voitetuksi.

\section{KH-NET-PROJEKTI N JATKUMINEN}

KH-NET-projektiin osallistuneet yritykset ovat suhtautuneet verkkoavusteiseen oppimiseen erittäin innostuneesti. Kiinteistönhoitajien oppimistulosten uskotaan yhä parantuvan seuraavissa koulutusohjelmissa.

\section{Tutkintoja projektin päättymisen jälkeenkin}

KH-NET-projektin aikana suurin osa kiinteistönhoitajista suoritti näyttötutkinnon. Verkko-opiskelu osoittautui tehokkaammaksi kuin ns. perinteinen opiskelumuoto. Projektin aikana osatutkintoja suorittaneista suurin osa jatkoi aktiivisesti verkko-opiskelua projektin jälkeenkin ja suoritti puuttuvat tutkinnon osat. Verkossa olevat valmennustehtävät osoittautuivat tehokkaiksi, ja niitä kehitetään edelleen.

\section{Lähtökohtana työelämän tarpeet}

Projektin lähtökohtana ovat olleet käytännön työelämän tarpeet. Työnantajien positiivisella suhtautumisella oli merkittävä vaikutus projektin onnistumiseen. Työpaikkaohjaajia valmennetaan jatkossa entistä tehokkaammin mm. verkko-oppimisen keinoin. Etelä-Suomen lääninhallitukselta ja Euroopan sosiaalirahastosta on haettu rahoitusta kyseiseen projektiin. Opiskelijoiden ja työ- paikkaohjaajien kirjoitusteknisiä valmiuksia pyritään parantamaan jatkossa. Nyt [tammikuussa 2003] kiinteistöala-tiimissä suunnitellaan lähijaksoille ja verkko-oppimiseen osioita, jotka valmentavat mm. tekstin tuottamiseen. Kirjoituskynnystä pyritään madaltamaan. Näin saadaan enemmän ns. kaupankäyntivyöhykkeitä eli opiskelijoiden, työpaikkaohjaajien, kurssivastaavien ja asiantuntijoiden tietotaitojen jakamista.

\section{Positiiviset kokemukset synnyttäneet uusia ryhmiä}

KH-NET-projektin jälkeen on aloittanut kaksi verkko-avusteista kiinteistönhoitajan ammattitutkintoon valmistavaa ryhmää. Suurin osa osallistujista on projektiin osallistuneista yrityksistä eli projektia voidaan pitää tässäkin mielessä onnistuneena.

\section{Lisätietoja}

Projektipäällikkö Arto Jääskeläinen, puh (09)

5307373, arto.jaaskelainen@ael.fi

Tuotepäällikkö Jukka Kari, puh (09) 5307 363, jukka.kari@ael.fi

Tuotepäällikkö Kirsi Kyllönen, puh. (09) 5307 346, kirsi.kyllonen@ael.fi

www.ael.fi, www.aelfi/koulutus/kiinteistoala 